\title{
Solid-phase Extraction of Estradiol-17 $\beta$ from Bovine Blood Plasma for its Peripheral Detection by Radioimmunoassay
}

\author{
Makoto HIRAKO, Naoki TAKENOUCHI') and Ikuo DOMEKI²) \\ Department of Animal Reproduction, National Institute of Animal Industry, Kukizaki, \\ Ibaraki 305-0901, ")Department of Animal Production, Tohoku National Agricultural \\ Experiment Station, Morioka, Iwate 020-0123, and ${ }^{2)}$ Department of Animal Science, \\ Tokyo University of Agriculture, Setagaya, Tokyo 156-0054, Japan
}

\begin{abstract}
A solid-phase extraction procedure for estradiol-17 $\beta$ from bovine blood plasma with a reversed phase cartridge was developed for the measurement of its concentration by radioimmunoassay. Estradiol- $17 \beta$ retained in the cartridge was eluted quantitatively with $70 \%(\mathrm{~V} / \mathrm{V})$ methanol, although estrone was recovered in the same fraction. The apparent values measured by dextrancoated charcoal radioimmunoassay with an eluent of $75 \%(\mathrm{~V} / \mathrm{V})$ methanol in the solid-phase extraction declined approximately by $10 \%$ as applied plasma volume was increased by $1 \mathrm{ml}(\mathrm{r}=-0.98, \mathrm{p}<0.001)$. However, the values by double antibody radioimmunoassay were elevated approximately $8 \%$ per 1 $\mathrm{ml}$ plasma increase $(\mathrm{r}=0.82, \mathrm{p}<0.001)$. The recovery of estradiol- $17 \beta$ added to bovine plasma in the extraction and radioimmunoassay with dextran-coated charcoal separation was approximately $75 \%$ under conditions of $2 \mathrm{ml}$ plasma application, and concentrations calculated using buffer standards. Matrix effects on the assay recovery were negligible in the addition of solid-phase extract of castrated bull plasma to the standards. On the other hand, the average recoveries calculated with buffer and process standards in double antibody radioimmunoassay were $170 \%$ and $110 \%$, respectively. The assay value in the solid-phase extraction showed good agreement with the value in the liquidliquid extraction and liquid chromatography after correction with the recovery rate $(r=0.99)$. In conclusion, solid-phase extraction with a reversed phase cartridge is a practical extraction method for the measurement of estradiol-17 $\beta$ during the estrous cycle in cattle.

Key words: Cattle, Estradiol-17 $\beta$, Radioimmunoassay, Solid-phase extraction.
\end{abstract}

(J. Reprod. Dev. 45: 183-189, 1999)

$\mathbf{P}$ eripheral estradiol-17 $\beta$ concentration is an important diagnostic index for the follicular condition $[1,2]$. Several preparation steps are required before assay procedure to detect estradiol-17 $\beta$ in bovine peripheral blood during estrous cycle due to its low concentration [3-6]. Liquid-liquid extraction followed by liquid chromatography is widely utilized as a reliable sample

Accepted for publication: December 18, 1998

Correspondence: M. Hirako

Present address: Department of Grazing Animal Production, National Grassland Research Institute, Nishinasuno, Tochigi 329-2793, Japan preparation method for measuring estradiol-17 $\beta$ levels in cattle $[3,4,7]$. However, the validated preparation method for radioimmunoassay of estradiol- $17 \beta$ is still complicated.

Solid-phase extraction with a reversed phase cartridge is utilized for analyzing estrogens in human blood because of its simplicity and reliability [8]. In cattle, unconjugated estrogens in blood plasma are retained in the cartridge as well [9]. However, it has not yet been shown whether estradiol-17 $\beta$ can be quantitatively measured by immunoassay with the solid phase extract.

The objective of this study was to develop a sim- 
ple and practical extraction method of estradiol$17 \beta$ using a reversed phase cartridge for the measurement of its concentration in bovine blood plasma.

\section{Materials and Methods}

\section{Animals, samples and reagents}

Regularly cycling Holstein, Japanese Black and Japanese Brown cows aged 2 to 5 yr were used in this study. Sample preparation and reagents utilized for the extraction of estradiol- $17 \beta$ have already been described in previous reports $[9,10]$.

\section{Solid-phase extraction}

A reversed phase cartridge (SEP-PAK Plus $\mathrm{C}_{18}$, Waters, Milford, U.S.A.) was activated with $5 \mathrm{ml}$ of methanol, then washed with $10 \mathrm{ml}$ of refined water. Bovine blood plasma was applied to the cartridge, followed by a couple of 5-ml water washes. Estradiol- $17 \beta$ adsorbed to the cartridge was eluted under the conditions of each experiment described below. The brief procedure for solidphase extraction and radioimmunoassay of estradiol-17 $\beta$ is outlined in Fig. 1.

\section{Liquid-liquid extraction and liquid chromatography}

Liquid-liquid extraction of estradiol-17 $\beta$ from bovine blood plasma was performed in accordance with a previous report [7]. Liquid chromatography of extracted estradiol-17 $\beta$ was partly modified from the original method [11]. Briefly, $2 \mathrm{ml}$ of reconstituted Sephadex LH-20 gel (Pharmacia, Upsala, Sweden) was packed into an interchangeable 2-ml glass syringe. A benzene and methanol mixture (85:15) was used as the moving phase. Liquid-liquid extract evaporated and reconstituted in $0.2 \mathrm{ml}$ of the moving phase was applied. Then, 2.3 $\mathrm{ml}$ of the moving phase was added and the eluent was disposed. Next $1.7 \mathrm{ml}$ was recovered for the measurement of estradiol-17 $\beta$. The recovery of estradiol- $17 \beta$ in the liquid-liquid extraction and liquid chromatography was approximately $70 \%$.

\section{Preparation of process standard for radioimmunoassay}

Castrated bull plasma, $20 \mathrm{ml}$, was applied in quadruplicate to four different cartridges, followed by a couple of $5-\mathrm{ml}$ water washes and $3 \mathrm{ml}$ of $40 \%$ $(\mathrm{V} / \mathrm{v})$ methanol. Each eluent of $75 \%(\mathrm{~V} / \mathrm{v})$ metha-

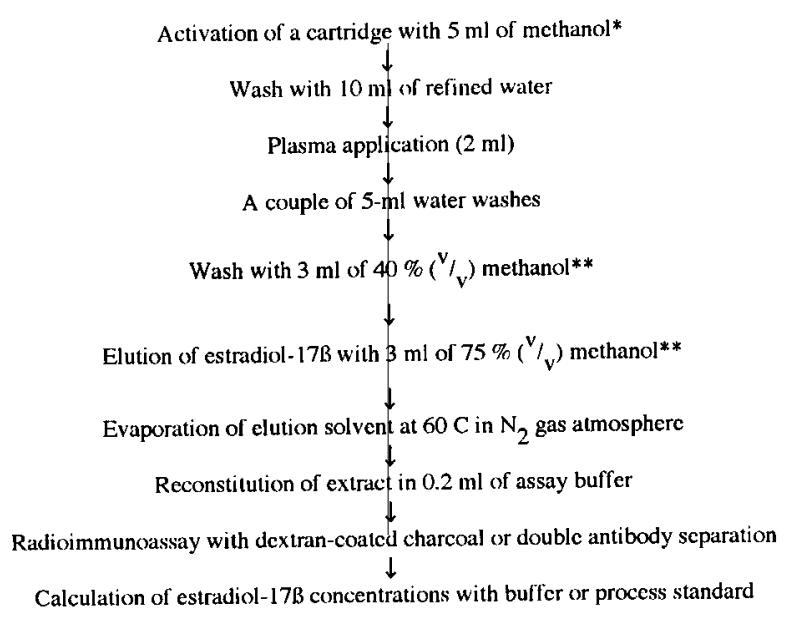

Fig. 1. Procedure for measurement of estradiol-17 $\beta$ in bovine blood plasma by solid-phase extraction and radioimmunoassay. *Special grade, ${ }^{* *}$ Methanol 1000, Wako Pure Chemical Ind., Osaka, Japan.

nol was evaporated and reconstituted in $2 \mathrm{ml}$ of assay buffer. The solution was mixed together and, $0.2 \mathrm{ml}$, added to each standard tube instead of simple buffer.

\section{Radioimmunoassay}

Recovered eluent was evaporated at $60 \mathrm{C}$ in a nitrogen gas atmosphere and reconstituted in the assay buffer. Estradiol-17 $\beta$ was measured by validated radioimmunoassay [12-14] with the reconstituted solution. Bound and free estradiol$17 \beta$ separation in the assays was performed with dextran-coated charcoal [12,13], or double antibody methods [14].

\section{Exp. 1. Solvent concentration for the elution of estrone and estradiol-17 $\beta$}

Approximately 7 and $8 \mathrm{pg} / \mathrm{ml}$ of tritium-labeled estrone and estradiol-17 $\beta$, respectively, were added to plasma collected from 5 cows in the follicular phase. Estrone and estradiol-17 $\beta$ were extracted from $5 \mathrm{ml}$ of the plasma and eluted in sequence with $3 \mathrm{ml}$ of $40,70 \%(\mathrm{~V} / \mathrm{v})$ and undiluted methanol and $3 \mathrm{ml}$ of diethyl ether. The radioactivity in each eluent was measured by a liquid scintillation method [9].

\section{Exp. 2. Effect of applied plasma volume on the assay value}

Plasma samples were collected from 10 cows in estrus. For each sample, 1, 2, 3, 4, 6 and $8 \mathrm{ml}$ of 
the plasma was applied in duplicate to two different cartridges. Following $3 \mathrm{ml}$ of $40 \%(\mathrm{~V} / \mathrm{v})$ methanol, estradiol- $17 \beta$ was eluted with $3 \mathrm{ml}$ of 75 $\%(\mathrm{~V} / \mathrm{v})$ methanol and measured by radioimmunoassay with dextran-coated charcoal $(\mathrm{N}=5)$ or second antibody $(\mathrm{N}=5)$ separation.

\section{Exp. 3. Assay recovery}

Estradiol-17 $\beta$ was added in concentrations of 8 , 16 and $32 \mathrm{pg} / \mathrm{ml}$ to 4 plasma mixtures. Each of the mixtures consisted of a combination of samples from 3 different cows in estrus or in the luteal phase. A couple of plasma mixtures in estrus and in the luteal phase were applied at $2 \mathrm{ml}$ in triplicate to three different cartridges for each assay. Estradiol-17 $\beta$ was eluted and measured in the same way as Exp. 2. Concentrations of estradiol-17 $\beta$ were calculated with buffer standards and process standards.

\section{Exp. 4. Correlation with a validated extraction method}

Twenty two plasma samples collected from 9 Holstein cows, 10 Japanese Black heifers and 3 Japanese Brown cows were used in this experiment. Estradiol- $17 \beta$ was extracted from $5 \mathrm{ml}$ of the plasma with two different extraction methods, the solid-phase extraction and the liquid-liquid extraction. The liquid-liquid extract was further refined with liquid chromatography. The eluent recovered from both the solid-phase extraction and liquid chromatography was evaporated and reconstituted in $0.5 \mathrm{ml}$ of assay buffer. Estradiol-17 $\beta$ was measured by dextran-coated charcoal radioimmunoassay with $0.2 \mathrm{ml}$ of the reconstituted solution. Estradiol-17 $\beta$ concentrations were calculated with buffer standard and compared on the presumption that the recoveries in the total assay systems by the solid-phase extraction and the liquid-liquid extraction followed by liquid chromatography were $75 \%$ and $70 \%$, respectively.

\section{Results}

Exp. 1. Solvent concentration for the elution of estrone and estradiol-17 $\beta$

The recovery profiles of estrone and estradiol$17 \beta$ are summarized in Table 1 . More than $98 \%$ of estrogens added to bovine plasma were adsorbed to the reversed phase cartridge. The total leakage of both estrogens from plasma effluent through $40 \%$ methanol was less than 3\%. Approximately $92 \%$ of estrone and $90 \%$ of estradiol- $17 \beta$ were eluted with $70 \%$ methanol although $6 \%$ of estrone and $7 \%$ of estradiol- $17 \beta$ still remained in the cartridge.

\section{Exp. 2. Effects of applied plasma volume on the} assay value

In radioimmunoassay with dextran-coated charcoal separation, the assay values declined as applied plasma volume was increased. As shown in Fig. 2, a negative correlation was observed be-

Table 1. Recovery rates of ${ }^{3} \mathrm{H}$-labeled estrone and estradiol$17 \beta$ added to bovine plasma in each fraction by the solid-phase extraction with a reversed phase cartridge $^{\mathrm{a})}$

\begin{tabular}{lcc}
\hline & $\begin{array}{c}\text { Estrone } \\
(\mathrm{N}=5)\end{array}$ & $\begin{array}{c}\text { Estradiol-17 } \beta \\
(\mathrm{N}=5)\end{array}$ \\
\hline Plasma effluent $\mathrm{b})$ & $0.97 \pm 0.08 \mathrm{c})$ & $1.53 \pm 0.09$ \\
Water wash-1 & $0.19 \pm 0.12$ & $0.28 \pm 0.04$ \\
Water wash-2 & $0.01 \pm 0.06$ & $0.02 \pm 0.03$ \\
$40 \%$ methanol & $1.08 \pm 0.03$ & $1.06 \pm 0.12$ \\
$70 \%$ methanol & $92.00 \pm 1.19$ & $89.94 \pm 1.71$ \\
Undiluted methanol & $5.73 \pm 1.13$ & $7.15 \pm 1.72$ \\
Diethyl ether & $0.02 \pm 0.01$ & $0.02 \pm 0.01$ \\
\hline
\end{tabular}

a) The methanol concentration in the elution solvent was increased stepwise from 40 to $70 \%(\mathrm{~V} / \mathrm{v})$ to undiluted.

b) Plasma and each water fraction is $5 \mathrm{ml}$, organic solvent is $3 \mathrm{ml}$ in each.

c) Mean \pm S.D. $(\%)$

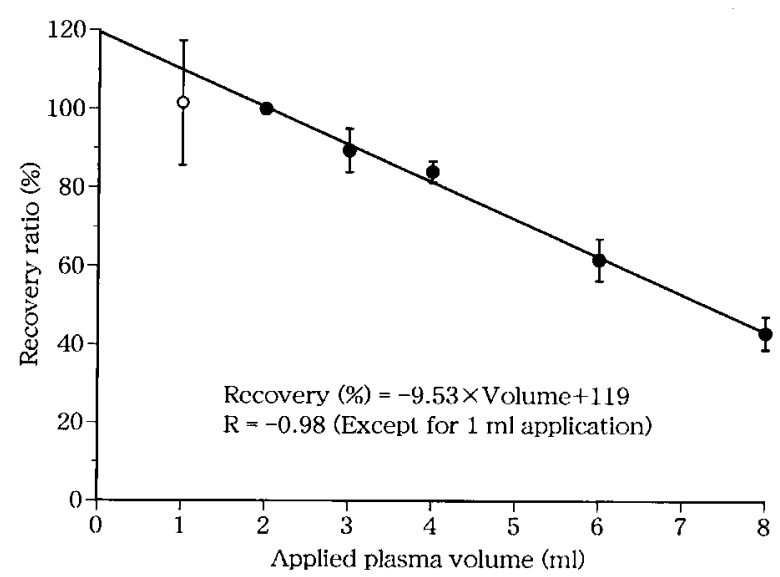

Fig. 2. Ratio (\%) of the apparent concentration of estradiol$17 \beta$ in each plasma volume to the value in the 2$\mathrm{ml}$ application (Mean \pm S.D.; $\mathrm{N}=5$ ). Estradiol-17 $\beta$ was directly measured by radioimmunoassay after the extraction. B/F separation in the assay was performed with dextran-coated charcoal. Estradiol$17 \beta$ concentrations at $2-\mathrm{ml}$ application ranged from 11.8 to $25.2 \mathrm{pg} / \mathrm{ml}$. 
tween the plasma volume and the assay value $(\mathrm{r}=$ $-0.98, p<0.001)$, and apparent concentrations were reduced approximately by $10 \%$ as applied plasma volume was increased by $1 \mathrm{ml}$. However, the assay values by radioimmunoassay with double antibody separation were elevated as applied plasma volume was increased. As shown in Fig. 3, a positive correlation was observed between the plas-

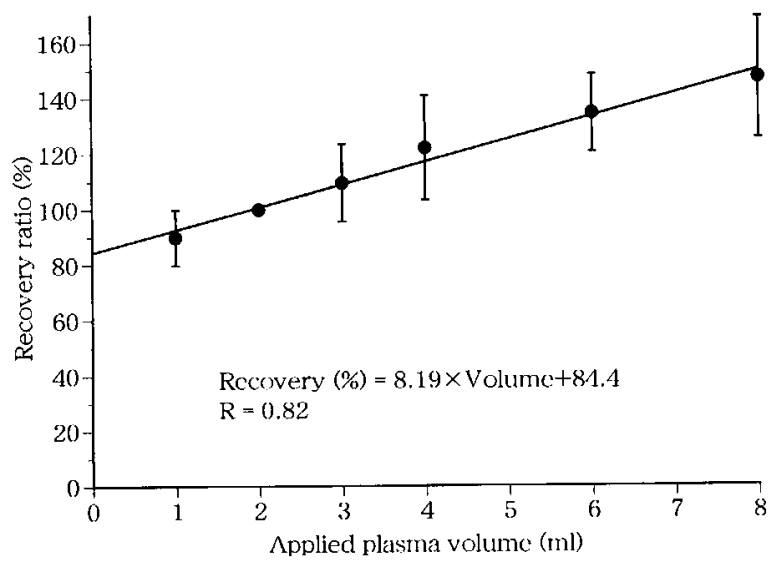

Fig. 3. Ratio (\%) of the apparent concentration of estradiol$17 \beta$ in each plasma volume to the value in the 2$\mathrm{ml}$ application (Mean \pm S.D.; $\mathrm{N}=5$ ). Estradiol-17 $\beta$ was directly measured by radioimmunoassay with double antibody B/F separation after the extraction. Estradiol-17 $\beta$ concentrations at 2-ml application ranged from 8.4 to $18.4 \mathrm{pg} / \mathrm{ml}$. ma volume and the assay value $(\mathrm{r}=0.82, \mathrm{p}<0.001)$, and apparent concentrations increased approximately by $8 \%$ with $1 \mathrm{ml}$ increases in applied plasma volume.

\section{Exp. 3. Assay recovery}

The recovery rate of estradiol- $17 \beta$ added to bovine plasma in the solid-phase extraction and radioimmunoassay is shown in Table 2 . The amount of estradiol-17 $\beta$ recovered by radioimmunoassay with dextran-coated charcoal separation ranged from 69 to $82 \%$ according to the calculation with buffer standards, whereas it ranged from 88 to $104 \%$ with process standards. On the other hand, as shown in Table 2, the recovery rate by radioimmunoassay with double antibody separation ranged from 149 to $192 \%$ with buffer standards and from 97 to $124 \%$ with process standards.

\section{Exp. 4. Correlation with a validated extraction method}

Estradiol-17 $\beta$ concentrations measured by radioimmunoassay following the two different preparatory steps are shown as a scatter graph in Fig. 4. The assay value with the solid-phase extract showed good agreement with the value in the liquid-liquid extraction and liquid chromatography $(\mathrm{r}=0.99)$. The regression coefficient and constant of the value in the solid-phase extraction

Table 2. Recovery of estradiol-17 $\beta$ added to bovine plasma by solid-phase extraction and radioimmunoassaya)

\begin{tabular}{|c|c|c|c|c|c|}
\hline & \multirow{2}{*}{$\begin{array}{c}\text { Added } \\
\text { estradiol-17 } \beta \\
\text { concentration } \\
(\mathrm{pg} / \mathrm{ml})\end{array}$} & \multicolumn{2}{|c|}{ Dextran-coated charcoalb) } & \multicolumn{2}{|c|}{ Double antibodyc) } \\
\hline & & $\begin{array}{c}\text { Bufferd) } \\
(\%)\end{array}$ & $\begin{array}{c}\text { Plasmae) } \\
(\%)\end{array}$ & $\begin{array}{c}\text { Buffer } \\
(\%)\end{array}$ & $\begin{array}{c}\text { Plasma } \\
(\%)\end{array}$ \\
\hline \multirow[t]{3}{*}{ Plasma 1 f) } & 8 & 78 & 88 & 149 & 97 \\
\hline & 16 & 82 & 101 & 158 & 105 \\
\hline & 32 & 74 & 99 & 179 & 114 \\
\hline \multirow[t]{3}{*}{ Plasma 2 g) } & 8 & 73 & 93 & 176 & 118 \\
\hline & 16 & 78 & 104 & 189 & 124 \\
\hline & 32 & 69 & 100 & 192 & 118 \\
\hline
\end{tabular}

a) Estradiol-17 $\beta$ added to bovine plasma was extracted with a reversed phase cartridge and eluted with $3 \mathrm{ml}$ of $75 \%(\mathrm{~V} / \mathrm{v})$ methanol after washing of the cartridge with $10 \mathrm{ml}$ of refined water and $3 \mathrm{ml}$ of $40 \%(\mathrm{~V} / \mathrm{V})$ methanol followed by radioimmunoassay.

b) Bound and free estradiol- $17 \beta$ were separated with dextran-coated charcoal.

c) B/F separation was performed with the double antibody method.

d) Estradiol-17 $\beta$ concentrations were calculated with buffer standards.

e) Estradiol- $17 \beta$ concentrations were calculated with the standards containing solid-phase extract of castrated bull plasma.

f) Two milliliter plasma mixture collected from 3 cows in the luteal phase.

g) Two milliliter plasma mixture collected from 3 cows in estrus. 


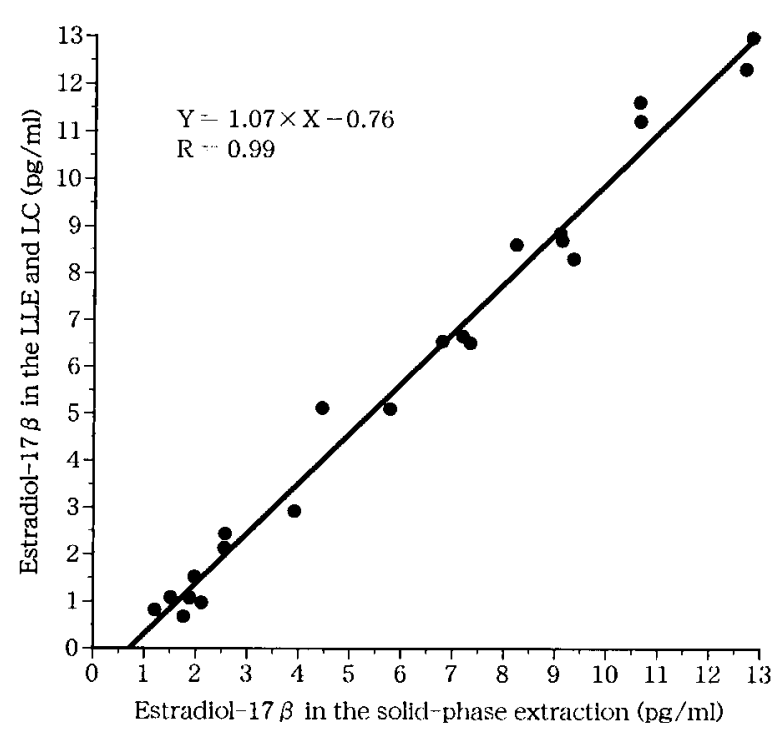

Fig. 4. Correlation of the assay values $(\mathrm{N}=22)$ of estradiol$17 \beta$ between the solid-phase extraction and the liquid-liquid extraction (LLE) and liquid chromatography (LC).

to those of the validated method are $1.07(\mathrm{p}<0.0001)$ and $-0.76 \mathrm{pg} / \mathrm{ml}$, respectively.

\section{Discussion}

Solid-phase extraction of estrogen from bovine blood plasma with a reversed phase cartridge has several advantages over liquid-liquid extraction followed by liquid chromatography in that it has no need for specific ventilation systems and technical skills, and plasma volume scarcely affects the extraction procedure. It requires shorter working hours as well, even though it takes much time to evaporate the eluent. If it is possible to measure estradiol-17 $\beta$ concentrations in bovine peripheral blood during regular estrous cycle by immunoassay with the solid-phase extract without any other purification steps, its applicability could be extended to the diagnosis of bovine reproductive disorders.

In Exp. 1, estrogens added to bovine plasma were quantitatively retained in the cartridge as previously reported [9], and were eluted with $70 \%$ methanol. As major conjugated estrogens in bovine plasma were eluted with $40 \%$ methanol [10], the results in Exp. 1 suggest that unconjugated estrogens are separated from conjugated estrogens by the stepwise gradient of methanol concentra- tion in the solid-phase extraction. However, it was impossible to separate estrone and estradiol-17 $\beta$ in the same way because both unconjugated estrogens were eluted in the same fraction.

Estrogens were quantitatively eluted with $70 \%$ methanol in Exp. 1. However, several percentages of added estrogens still remained in the cartridge and were recovered with undiluted methanol. So, a higher concentration, e.g. $75 \%$, of methanol may be better for the elution of unconjugated estrogens. Nevertheless, impurities in the eluent increase as the solvent concentration is elevated.

In Exp. 2, apparent concentrations of estradiol$17 \beta$ measured by radioimmunoassay with dextrancoated charcoal separation declined as applied plasma volume was increased (Fig. 2), whereas they were elevated with plasma increase in radioimmunoassay with double antibody separation (Fig. 3). According to a previous report [9], the recovery of estradiol- $17 \beta$ in the solid-phase extraction is consistent regardless of applied plasma volume. These results indicate that some substances contained in the plasma and eluted together with estradiol-17 $\beta$ interfere with the reaction of the radioimmunoassay. The inverse results in radioimmunoassay with dextran-coated charcoal separation and double antibody separation further suggest that the matrix effect would appear on the adsorption of estradiol-17 $\beta$ to the charcoal as well as its immunoreaction to the antibody. It is also considered that the interfering substances are contained in bovine plasma at a constant rate because the regression rate of apparent concentration was highly correlated with the applied plasma volume regardless of individual plasma (Figs. 2 and 3).

As shown in Table 2, the average recovery rate of estradiol- $17 \beta$ added to bovine plasma in the extraction and radioimmunoassay with dextrancoated charcoal separation was $75 \%$, which was consistent with the results in Exp. 2. These results suggest that the precise concentration of estradiol$17 \beta$ in bovine plasma can be calculated assuming that the recovery in the extraction and radioimmunoassay with dextran-coated charcoal separation is between 70 to $80 \%$ when $2 \mathrm{ml}$ of the plasma is applied. On the other hand, the recoveries by radioimmunoassay with double antibody separation were elevated with the increase in added quantity (Table 2). Considering the recoveries of original concentrations, the recoveries were almost fixed at approximately $190 \%$ but inconsistent with the re- 
sults in Exp. 2 (120\% at $2 \mathrm{ml})$. The results in Exp. 2 and 3 indicate that the solid-phase extract of bovine plasma inhibits the binding of estradiol-17 $\beta$ to dextran-coated charcoal as well as its antibody. Inhibition of the binding to the antibody increases the apparent concentrations calculated with buffer standards and inhibition of the binding to dextran-coated charcoal reduces the apparent concentrations. It is considered that the matrix effects were consequently modest in radioimmunoassay with dextran-coated charcoal separation because the effects on the binding to the antibody were offset by the effects on the adsorption of dextran-coated charcoal. These results suggest that dextran-coated charcoal separation is more appropriate for radioimmunoassay of estradiol- $17 \beta$ in the solid-phase extract of bovine blood plasma if the concentration is calculated with buffer standards.

The recovery rates were more quantitative in calculating the concentration with standards containing solid-phase extract of castrated bull plasma in radioimmunoassay with dextran-coated charcoal separation (Table 2). Even in radioimmunoassay with double antibody separation, calculation with the process standards made the recoveries quantitative (Table 2). These results indicate that matrix effects on the radioimmunoassay were negligible when using the process standards. However, correction of the apparent concentration with the recovery rate of already-known samples is a more practical procedure for calculating the precise concentration since preparation of the pro- cess standards makes the assay procedure complicated.

The assay value with the solid-phase extract showed a high correlation with the value in the liquid-liquid extraction and liquid chromatography in Exp. 4 (Fig. 4). The regression coefficient and constant of the assay values between both preparatory methods were also satisfactory. These results indicate that the solid-phase extraction is reliable as a preparatory method for radioimmunoassay of estradiol-17 $\beta$ in bovine blood plasma. Furthermore, the solid-phase extraction is considered to be more practical than the conventional method due to its simple procedure. Notwithstanding that, the solid-phase extraction cannot separate estradiol-17 $\beta$ and estrone as shown in Table 1 , but the conventional method can $[3,4,7,11]$. Therefore, crossreactivity of antibody is a key factor in immunoassay of estrogens with the solid-phase extract.

In conclusion, solid-phase extraction using a reversed phase cartridge is a simple and practical preparation method for measuring estradiol- $17 \beta$ in bovine peripheral blood by radioimmunoassay. In practice, it is suggested that $2 \mathrm{ml}$ bovine blood plasma be applied to a reversed phase cartridge; estradiol- $17 \beta$ be eluted with $3 \mathrm{ml}$ of $75 \%(\mathrm{~V} / \mathrm{v})$ methanol following two washes with 5-ml of water, and a $3 \mathrm{ml}$ wash of $40 \%(\mathrm{~V} / \mathrm{v})$ methanol, and measured by radioimmunoassay after evaporation of the eluent; then its concentration can be calculated with approximate standards and recovery rates.

\section{References}

1. Gore-Langton RE, Armstrong DT. Follicular steroidogenesis and its control. In: Knobil E, Neill JD (eds.), The Physiology of Reproduction., 2nd ed., Vol. 1. New York: Raven Press; 1994: 571-627.

2. Hafez ESE. Folliculogenesis, egg maturation and ovulation. In: Hafez ESE (ed.), Reproduction in Farm Animals., 5th ed. Philadelphia: Lea \& Febiger; 1987: 130-167.

3. Mikhail G, Wu C H, Ferin M, Van de Wiele RL. Radioimmunoassay of plasma estrone and estradiol. Steroids 1970; 15: 333-352.

4. Torii R, Imori T. Simple assay method for bovine plasma progesterone, estrone, estradiol, estriol, cortisol, and corticosterone. Jpn J Anim Reprod 1975; 20: 153-164 (In Japanese).

5. Medina MB, Schwartz DP. Isolation of estrogens in bovine plasma and tissue extracts using alumina and ion-exchange microcolumns. J Agric Food Chem 1986; 34: 907-910.

6. Nagata S, Kondou M, Kaneko H, Araki K, Nambo Y, Oikawa M, Watanabe G, Taya K. A simple defatting method using a partition method of acetonitrile and $\mathrm{n}$-hexan for radioimmunoassay of low blood levels of estradiol-17 $\beta$. J Reprod Develop 1996; 42: j43-j49 (In Japanese).

7. Domeki I, Nakahara T. Peripheral plasma estrogen and progesterone levels during the estrous cycle and early pregnancy in the cow. Jpn J Anim Reprod 1977; 23: 29-34 (In Japanese).

8. Heikkinen R, Fotsis T, Adlercreutz H. Reversedphase $\mathrm{C}_{18}$ cartridge for extraction of estrogens from urine and plasma. Clin Chem 1981; 27: 1186-1189. 
9. Hirako M, Kamomae H, Domeki I. Solid-phase extraction of estrogens from bovine blood plasma. J Vet Med Sci 1992; 54: 399-402.

10. Hirako M, Takahashi H, Domeki I. Establishment of a reliable extraction method of estrone sulfate from bovine plasma for detection of the peripheral level during the regular estrous cycle by radioimmunoassay. Domestic Anim Endocrinol 1996; 13: 187-195.

11. Makino T. Radioimmunoassay of sex steroid hormone. Jpn J Endocrinol 1973; 49: 629-645 (In Japanese).
12. Nakamura T, Shodono M, Tanabe $\mathbf{Y}$. A manual of radioimmunoassay of estradiol and progesterone in animal tissues and fluids. Res Bull Fac Agr Gifu Univ 1974; 36:319-328 (In Japanese).

13. Patel OV, Hirako M, Takahashi T, Sasaki N, Domeki I. Sex steroid levels throughout gestation in cows carrying normal and malformed fetuses. J Vet Med Sci 1995; 57: 659-663.

14. Saumande J, Batra SK. A double antibody radioimmunoassay for free and conjugated estradiol-17 beta in cow's milk. Steroids 1984; 44: 137-152. 